\title{
SEPARATIONS AND WASTE FORMS CAMPAIGN IMPLEMENTATION PLAN
}

\section{Fuel Cycle Research \& Development}

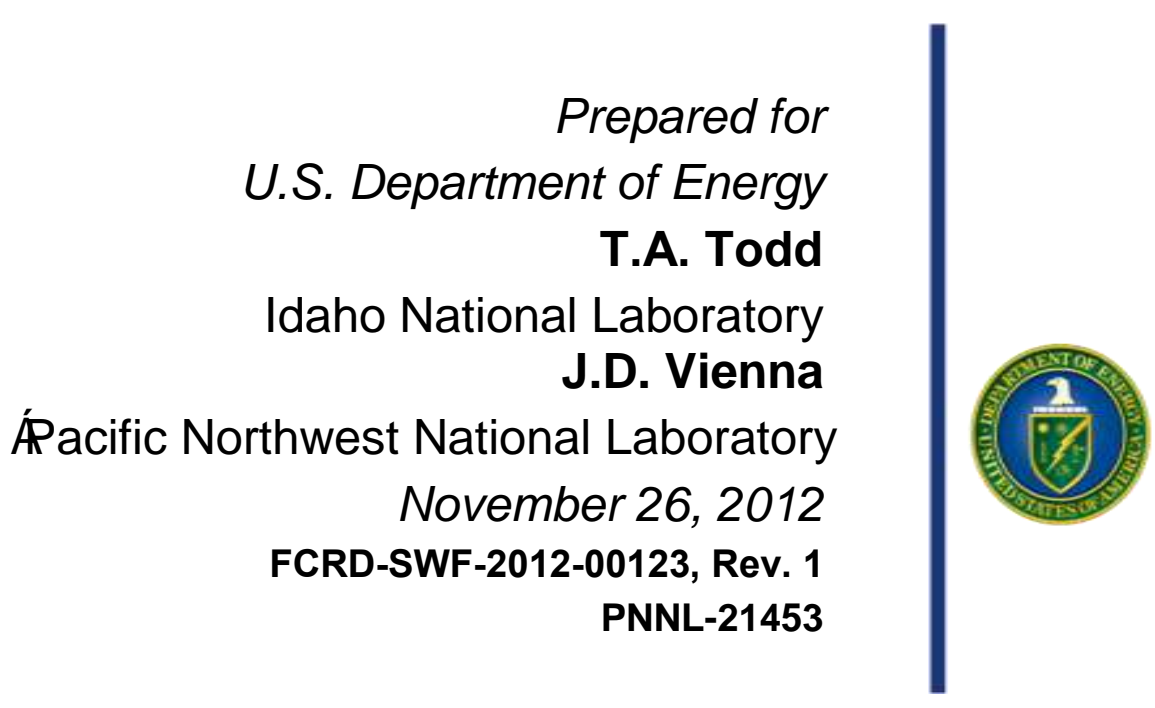




\section{DISCLAIMER}

This information was prepared as an account of work sponsored by an agency of the U.S. Government. Neither the U.S. Government nor any agency thereof, nor any of their employees, makes any warranty, expressed or implied, or assumes any legal liability or responsibility for the accuracy, completeness, or usefulness, of any information, apparatus, product, or process disclosed, or represents that its use would not infringe privately owned rights. References herein to any specific commercial product, process, or service by trade name, trade mark, manufacturer, or otherwise, does not necessarily constitute or imply its endorsement, recommendation, or favoring by the U.S. Government or any agency thereof. The views and opinions of authors expressed herein do not necessarily state or reflect those of the U.S. Government or any agency thereof. 


\section{Approved by:}

National Technical Director

Federal Program Manager

Fuel Cycle Research and Development Director
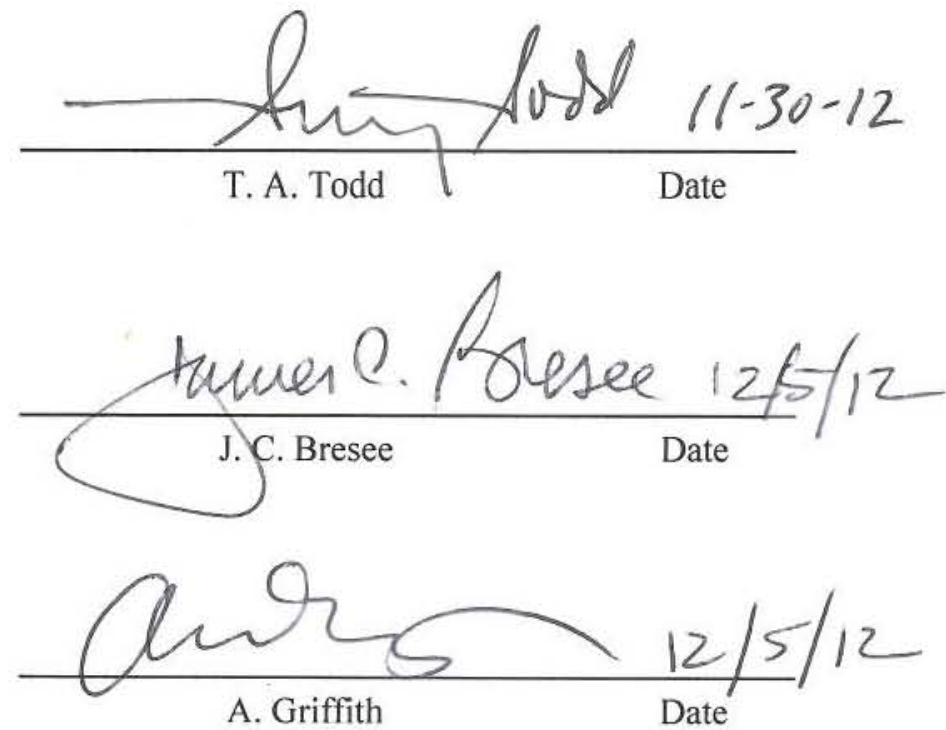


\section{FCT Quality Assurance Program Document}

\section{FCT Document Cover Sheet}

Name/Title of Deliverable/Milestone

Work Package Title and Number

Work Package WBS Number

Responsible Work Package Manager
M3FT-12PN0301022: Update separations and waste forms campaign implementation plan

FT-12PN030102: Campaign Management and Integration - PNNL

J.D. Vienna (electronic signature)

(Name/Signature)

Date Submitted

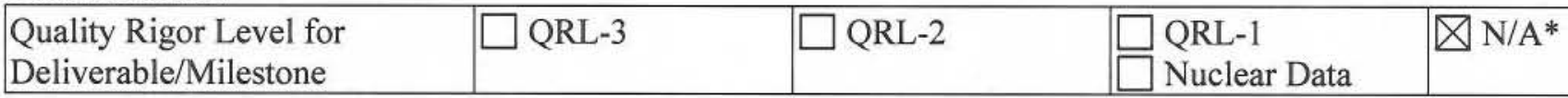

This deliverable was prepared in accordance with

QA program which meets the requirements of

Pacific Northwest National Laboratory

(Participant/National Laboratory Name)

\section{$\triangle$ DOE Order 414.1 $\square$ NQA-1-2000}

This Deliverable was subjected to:

$\bigotimes$ Technical Review

Technical Review (TR)

Review Documentation Provided

Signed TR Report or,

Signed TR Concurrence Sheet or,

$\triangle$ Signature of TR Reviewer(s) below

\section{Name and Signature of Reviewers}

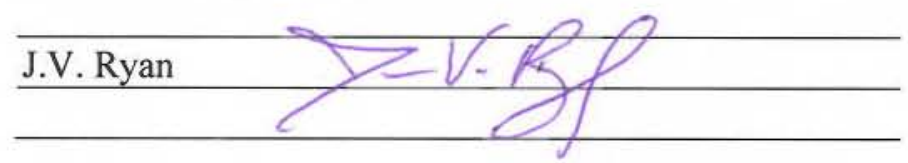

Peer Review

Peer Review (PR)

Review Documentation Provided

Signed PR Report or,

Signed PR Concurrence Sheet or,

Signature of PR Reviewer(s) below

*Note: In some cases there may be a milestone where an item is being fabricated, maintenance is being performed on a facility, or a document is being issued through a formal document control process where it specifically calls out a formal review of the document. In these cases, documentation (e.g., inspection report, maintenance request, work planning package documentation or the documented review of the issued document through the document control process) of the completion of the activity along with the Document Cover Sheet is sufficient to demonstrate achieving the milestone. QRL for such milestones may be also be marked N/A in the work package provided the work package clearly specifies the requirement to use the Document Cover Sheet and provide supporting documentation. 


\section{CONTENTS}

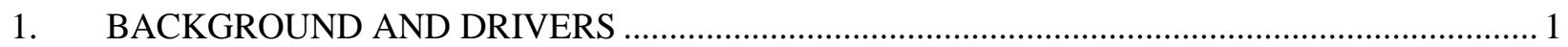

2. SEPARATIONS AND WASTE FORM TECHNICAL GAPS..................................................... 5

2.1 Separations and Waste Management in Historical Context ................................................. 5

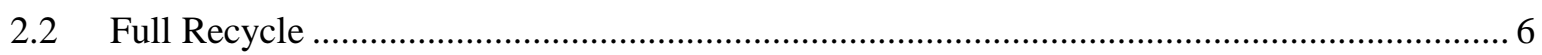

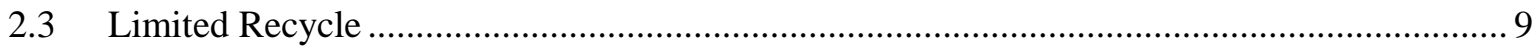

2.4 Open Cycle

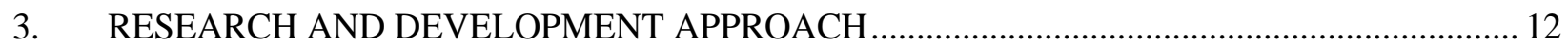

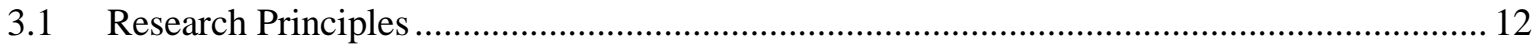

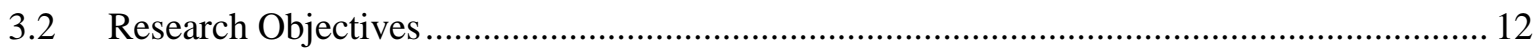

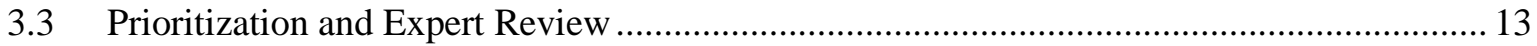

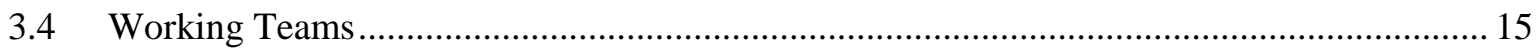

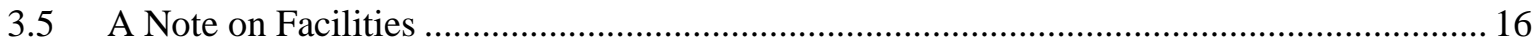

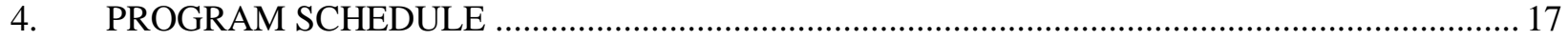

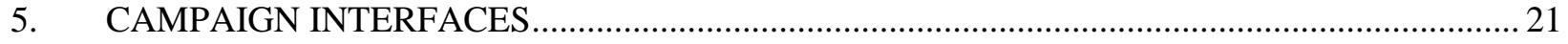

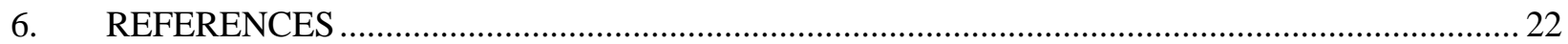




\section{BACKGROUND AND DRIVERS}

One of the U.S. Department of Energy's (DOE) missions is to ensure America's security and prosperity by addressing its energy, environmental, and nuclear challenges through transformational science and technology solutions. As the largest domestic source of low-carbon electricity, nuclear power is a major contributor toward enabling the nation to achieve its energy security and greenhouse gas emission reduction objectives. In the DOE 2011 strategic plan, the DOE nuclear responsibilities were stated to include "the development of safe storage and final disposition of used nuclear fuel, as well as the cleanup of our Cold War legacy. The Department supports the President's call to work with other nations to build "a new framework for civil nuclear cooperation" so that countries can access peaceful power without increasing the risks of proliferation. There is a huge potential to engage the expertise of U.S. industry, our national laboratories, and universities in the challenges of better using the energy of nuclear fuel; enhancing proliferation resistance; and reducing the volume, the toxicity, and the lifetime of waste streams.(DOE 2011b)
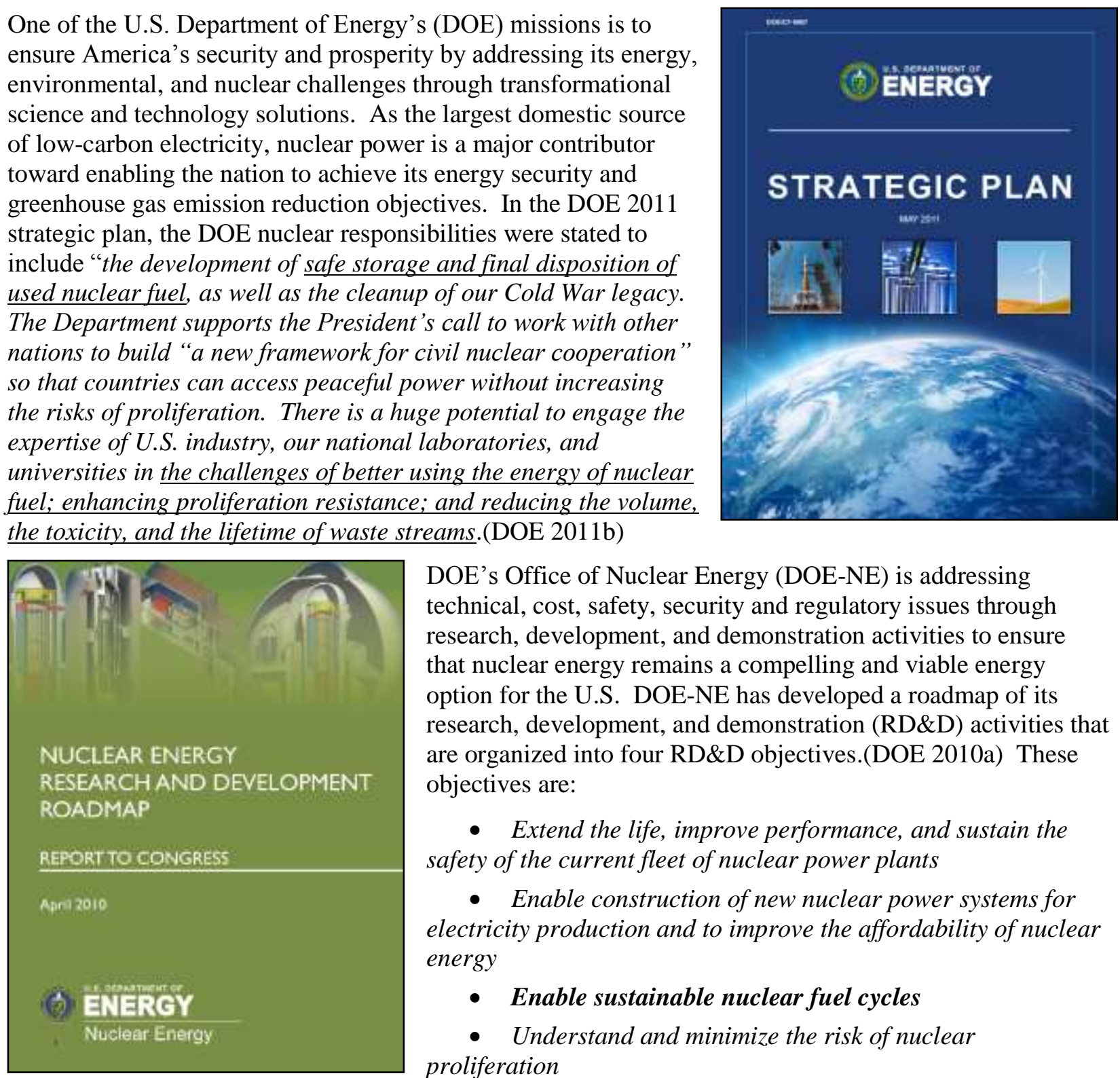

DOE's Office of Nuclear Energy (DOE-NE) is addressing technical, cost, safety, security and regulatory issues through research, development, and demonstration activities to ensure that nuclear energy remains a compelling and viable energy option for the U.S. DOE-NE has developed a roadmap of its research, development, and demonstration (RD\&D) activities that are organized into four RD\&D objectives.(DOE 2010a) These objectives are:

- Extend the life, improve performance, and sustain the safety of the current fleet of nuclear power plants

- Enable construction of new nuclear power systems for electricity production and to improve the affordability of nuclear energy

\section{- Enable sustainable nuclear fuel cycles}

- Understand and minimize the risk of nuclear proliferation

Enabling sustainable nuclear fuel cycles and options along with developing used nuclear fuel (UNF) management strategies and technologies to support the U.S. federal government's responsibility to manage and dispose of the U.S. commercial UNF and associated high level waste (HLW) are key elements in the mission of the DOE-NE Office of Fuel Cycle Technologies. There are three primary aspects to be considered in achieving sustainable fuel cycles:(DOE 2010b)

- $\quad$ Availability of fuel resources - As a dominant source of nuclear fuel, uranium is mined in many countries and traded internationally as a commodity. There is concern that if the global use of nuclear power grows, the supply of uranium for fuel could tighten and lead to challenges securing fuel at reasonable prices in an environmentally sustainable manner. 
- Improving utilization of fuel resources while minimizing the generation of nuclear waste - New reactor designs and fuel cycle options may help to alleviate concerns about fuel resources and waste management by enabling the extraction of more energy from the nuclear fuel. Doing this would reduce the amount of fuel required to maintain the reactor fleet while also leaving less used fuel to be managed.

- $\quad$ Adequate capability and capacity to manage all the nuclear wastes produced by the fuel cycle - A principle challenge is to develop a suite of options that will enable decision-makers to make informed choices about how best to manage the used fuel from nuclear reactors. Management will require safe storage of used fuel for some length of time prior to disposal or treatment. Various fuel cycle options exist that define the extent to which used fuel is further processed to remove key elements and the wastes that will require disposal. In addition to the used fuel and high level waste, secondary waste or byproducts will also require safe management and disposal.

Technological, regulatory, repository siting, safety, and economic issues will ultimately drive the consideration of advanced fuel cycles and new reactors. The Office of Fuel Cycle Technologies holds as its primary objective the development of technologies to enable sustainable fuel cycles in the U.S. The office is partitioned into four primary program offices:

- Fuel Cycle Options and Systems Analyses

- Fuel Cycle Research and Development

- Used Fuel Disposition

- Uranium Management

The Fuel Cycle Research and Development (FCRD) program develops technologies for advanced fuel cycles and is comprised of three campaigns:

- Advanced Fuels Development Campaign (AFC)

- Separations and Waste Forms (SWF) Campaign

- Materials Protection, Accounting, and Control (MPACT) Campaign

Three potential fuel cycle approaches, each with many derivatives, are under evaluation by the Office of Fuel Cycle Technologies: once-through, limited recycle (once called a modified open fuel cycle), and full recycle (or closed fuel cycle). The SWF campaign activities contribute to all three potential options:

- Open-Cycle (OC) - technologies to improve the availability of low-cost fissile materials and reduce the environmental impacts of nuclear energy

- Limited-Recycle (LR) - technologies that more efficiently use uranium, reducing the amount of radioactive waste generated using limited processing

- Full-Recycle (FR) - technologies to repeatedly reprocess and recycle nuclear fuels, thereby minimizing the amount of radioactive waste generated.

Technologies for improved utilization of uranium from underutilized sources are common to all fuel cycle options. These include the extraction of uranium from seawater and technologies for recovering the fissile value of UNF. In addition, any nuclear material processing will generate waste that must be 
managed in a cost effective and environmentally responsible way that promotes the licensing, operation, and closure of waste disposal facilities. This campaign provides key input for comparing the current basis of a once-through fuel cycle with other options in addition to developing the technologies necessary to enable, sustainable, advanced fuel cycles.

A DOE sponsored workshop on Nuclear Separations Technologies identified the critical importance of separation technologies across four DOE mission areas and the technical challenges that need to be addressed. The final report stated that the following nuclear separations technology developments are required:(DOE 2011a)

(1) In the absence of a large commercial domestic market in nuclear separations, responsibility for developing these technologies falls to DOE. DOE should be capable of taking the necessary steps in behalf of our national interests to assure the technical capabilities exist to meet current and future nuclear separations needs.

(2) Nuclear separations $R D \& D$ requires highly specialized facilities, as many of the important species are radioactive and/or entail extensive safeguards and security. Preserving or developing specialized facilities for $R D \& D$, and maintaining internal centers of excellence, will ensure required capabilities are available.

(3) The U.S. reservoir of trained professionals [in nuclear separations] outside the DOE complex is small. Developing the next generation of young professionals to replace retiring staff is essential to maintain U.S. technical expertise in this important technology.

The study also highlighted a number of specific technology challenges that could be effectively addressed by joint research programs among the DOE Offices of Nuclear Energy, National Nuclear Security Administration, Environmental Management, and Science; including:(DOE 2011a)

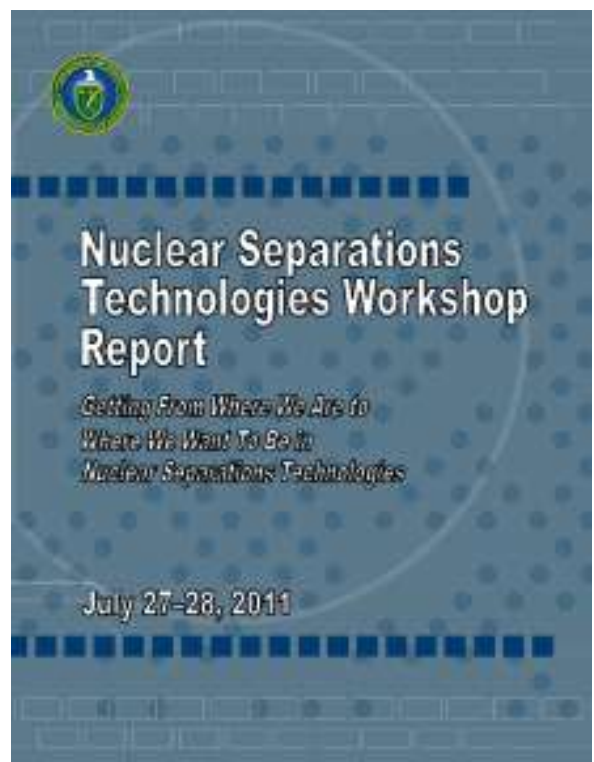

- Chemistry and speciation of the actinides and key fission products (Cs, Tc, I)

- Design of molecules with selective nuclear separations capability

- Scale-up to industrial capabilities

- Interface synergies between nuclear separations, waste management, and fuel fabrication

Additionally, the potential benefits of developing a nuclear separations center of knowledge were highlighted. This campaign performs research in each of these four topical areas to make possible advanced, sustainable, fuel cycles.

In January 2012, the Blue Ribbon Commission on America's Nuclear Future (BRC) issued its final report recommending eight strategic elements for addressing the backend of the fuel cycle in light of the decision to halt work on the nuclear waste repository at Yucca Mountain.(Hamilton et al. 2012) Although the Administration has not yet responded to the Commission's report, two of the Commissions major recommendations were already being addressed by the campaign:

7. Support for continued U.S. innovation in nuclear energy technology and for workforce development.

8. Active U.S. leadership in international efforts to address safety, waste management, nonproliferation, and security concerns. 
More specific descriptions of the research called for by the Commission in relation to this campaign include:(Hamilton et al. 2012)

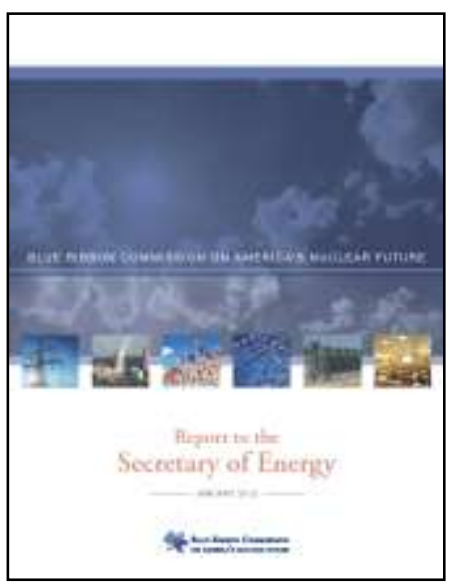

"The results of our qualitative assessment suggest that while it is too early to select "winners," advanced nuclear energy systems could offer a range of benefits in terms of broadly held policy goals with respect to safety, cost, security, etc."

"...the Commission concludes that the United States should continue to pursue a program of nuclear energy $R D \& D$ both to improve the safety and performance of existing nuclear energy technologies and to develop new technologies that could offer significant advantages in terms of the multiple evaluation criteria identified in our charter (i.e., safety, cost, resource utilization and sustainability, waste management, and non-proliferation and counterterrorism). We believe a well-designed federal $R D \& D$ program is critical to enabling the U.S. to regain its role as the global leader of nuclear technology innovation and should be attentive to opportunities in two distinct realms:

1. Near-term improvements in the safety and performance of existing light-water reactor technology as currently deployed in the United States and elsewhere as part of a once-through fuel cycle, and in the technologies for storing and disposing of SNF and HLW.

2. Longer-term efforts to advance potential 'game changing' nuclear technologies and systems that could achieve very large benefits across multiple evaluation criteria compared to current technologies and systems. Examples might include fast-spectrum reactors demonstrating passive safety characteristics that are capable of continuous actinide recycling and that use uranium more efficiently...

The Commission has recognized that near-term opportunities exist to improve the safety and performance of existing light water reactors (LWR) and spent fuel and high-level waste (HLW) storage, transport, and disposal systems. They emphasized that these near-term opportunities must also be complimented by the longer-term possibility that innovations offer potentially large advantages over current technologies and systems. Also included in this recommendation was the necessity to develop the skilled workforce to support effective waste management and the domestic nuclear industry.

The driving documents discussed above highlight the needs for the development of separations and waste management technologies. To better support these needs, the Separations and Waste Forms Campaigns were combined into a single Campaign in 2010. The Campaign objective is:

\section{Develop advanced separation and waste form technologies that improve current fuel cycle performance and enable a sustainable next generation fuel cycle with minimal processing, waste generation and potential for material diversion.}

This SWF Campaign Implementation Plan provides summary level detail describing how the Campaign will achieve the objectives set-forth by the FCRD Program. This implementation plan will be maintained as a living document and will be updated as needed in response to changes or progress in separations and waste forms research and the FCRD Program priorities. 


\section{SEPARATIONS AND WASTE FORM TECHNICAL GAPS}

\subsection{Separations and Waste Management in Historical Context}

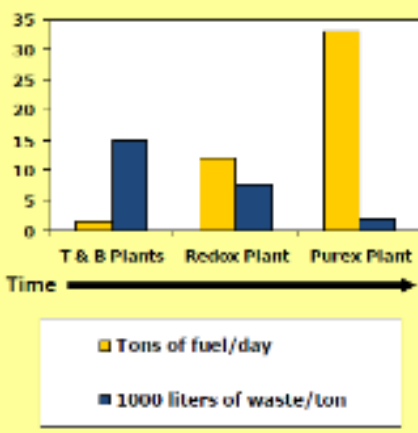

Waste generation rates for

Hanford heavy metal separations plants
Historically, the U.S. played a leadership role in the development of separation processes for nuclear materials. The U.S. led the world in heavy metal separations for defense purposes in the 1940's. In the 1950 's a new and more efficient process for plutonium and uranium recovery (the PUREX process) was introduced and eventually adopted by all reprocessing nations. The main objectives of this process were to separate pure $\mathrm{Pu}$ and pure $\mathrm{U}$ from irradiated fuel. This was accomplished by multiple solvent extraction steps using an organic extractant and an aqueous phase consisting of the used nuclear fuel dissolved in nitric acid. The solvent contained tri-butyl phosphate and kerosene and the process employed other chemicals such as reductants like ferrous sulfamate to separate plutonium from uranium. The high level waste containing fission products and minor actinides were discharged to underground tanks. Other waste streams were released to

the environment (ponds, atmosphere, trenches, etc.). These waste management practices, driven by the war time production demands, have created a challenging and costly legacy waste management problem. HLWs are being or slated to be vitrified into a durable glass waste form for ultimate disposal in a deep geologic repository.(DOE 1997)

Over the past several decades of commercial reprocessing in France, and the UK (and pilot scale in Japan), the separation technologies have been advanced beyond the original PUREX process resulting in significant improvements in waste generation and management, process efficiencies, materials accountancy, and environmental impacts. Plutonium and uranium are being recycled back into fresh reactor fuel in France, thereby more effectively using the potential of the fuel's fissile inventory to generate energy. The highly radioactive wastes are solidified into waste forms that may be more suitable for disposal of the fission products and minor actinides than the used fuel itself. This can be considered a second-generation process technology. The modern application of PUREX has addressed many of the concerns with separations technology that were prevalent during the

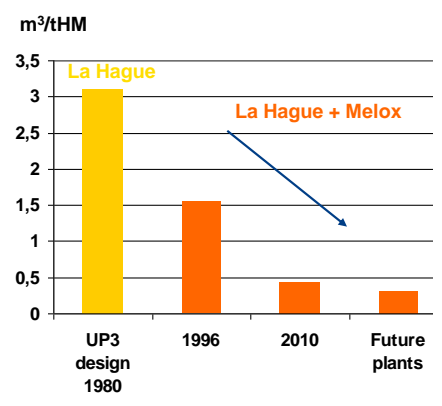

HLW and GTCC waste volume reduction in current PUREX cold-war; concerns that may have contributed to a generally negative impression of reprocessing in the U.S.

Recently, advanced third-generation reprocessing technologies have been developed to avoid the separation of pure plutonium. These processes use the same industrially-proven PUREX chemistry and equipment, but change process conditions and avoid production of pure plutonium by maintaining some uranium and possibly neptunium with the separated plutonium. This method of keeping a fraction of the uranium with the plutonium has been called co-extraction processes (e.g. COEX and NUEX).

Additionally, electrochemical (or pyrochemical) separation processes have been developed to reprocess metal fast reactor fuel. This process which utilizes a molten salt at approximately $500^{\circ} \mathrm{C}$ is designed to separate a relatively pure uranium stream and a combined uranium/TRU stream. The application of this technology for uranium recovery has been demonstrated on an engineering-scale and used to process a few tons of driver and blanket fuel from EBR-II and FFTF. The recovery of the U/TRU stream is less developed and only demonstrated at the gram and kilogram scales. Electrochemical processing has also been applied to reprocess LWR oxide fuel, by adding an additional electrochemical processing step. 
For the full recycle, limited recycle, and, to a lesser extent, open fuel cycles there is a need for advanced separations and waste management technology development.

\subsection{Full Recycle}

The current U.S. baseline for managing commercial UNF is direct disposal in a geologic repository after a single burn in a reactor. This has the advantage of no processing of UNF and reduced low-level waste (LLW) generation. However, compared with used fuel recycle, the disadvantages include increased mass and volume for geologic disposal, increased radiotoxicity associated with the waste (spent nuclear fuel, $\mathrm{SNF}$ ), a less durable disposal waste form requiring more elaborate engineered barriers, higher demand for uranium ore, and higher long-term heat for repository design. Advanced fuel cycles will reuse fissile content of UNF to some extent. In the case of fast reactors, minor actinides will be transmuted resulting in 8 to 12 times less HLWs than the amounts of UNF processed and will require less repository capacity when compared to direct disposal. Although the separations and waste forms technologies are not currently developed to the point necessary to implement one of these sustainable fuel cycles, preliminary results from the U.S. and abroad have demonstrated sufficient promise to be confident of success if the required technology development is performed. Successful development of such technologies would allow us to realize one of the "...potential 'game changing' nuclear technologies and systems that could achieve very large benefits across multiple evaluation criteria compared to current technologies..." referred to by the BRC.(Hamilton et al. 2012)

The following table represents a high level overview of the advancements made in reprocessing technologies and those required to obtain a truly sustainable fuel cycle.

\begin{tabular}{|l|l|l|l|}
\hline \multicolumn{1}{|c|}{ Past (history) } & \multicolumn{2}{c|}{ Present (options) } & \multicolumn{1}{c|}{ Future (needs) } \\
\hline Pu for weapons & UO burning only & Pu MOX & Recycle TRU \\
\hline PUREX & Once through & PUREX & Advanced separations \\
\hline $\begin{array}{l}\text { Waste stored in } \\
\text { tanks }\end{array}$ & $\begin{array}{l}\text { Local SNF } \\
\text { storage }\end{array}$ & $\begin{array}{l}\text { Immediate } \\
\text { waste treatment }\end{array}$ & $\begin{array}{l}\text { Consolidated } \\
\text { processing/storage }\end{array}$ \\
\hline Vent fission gasses & $n / a$ & $\begin{array}{l}\text { Vent or release } \\
\text { fission gasses }\end{array}$ & $\begin{array}{l}\text { Capture and immobilize } \\
\text { fission gasses }\end{array}$ \\
\hline Deferred vitrification & $\begin{array}{l}\text { Deferred Fuel } \\
\text { disposal }\end{array}$ & $\begin{array}{l}\text { Glass for future } \\
\text { disposal }\end{array}$ & $\begin{array}{l}\text { High performance waste } \\
\text { formsl geologic disposal }\end{array}$ \\
\hline
\end{tabular}

The implementation of a sustainable fuel cycle will require long-term investment in separations and waste management research. Technology developments must be made on a firm foundation of scientific understanding. This understanding will enhance our nation's ability to apply technologies to the ever changing requirements of potential flowsheets, license and operate these new facilities, and support the screening and demonstration of technologies and fuel cycle components. Technologies developed for a fast reactor fuel cycle must also be amenable to commercial deployment. This demands a cost effective, robust, and integrated process where each individual technology or unit operation is integrated into an entire flowsheet. With these two overriding principles in mind, the primary technological gaps for a full recycle flowsheet are:

1. The ability to efficiently separate the minor actinides (MAs) from the chemically similar lanthanides (Ln) and potentially from each other in an aqueous reprocessing flowsheet. Several technologies have been suggested to separate MA from Ln including Trivalent ActinideLanthanide Separations by Phosphorus-reagent Extraction from Aqueous Complexes (TALSPEAK)(Weaver and Kappelmann 1968), a single step combination of Transuranic Extraction (TRUEX) and TALSPEAK dubbed TRUSPEAK or ALSEP(Lumetta et al. 2010), DIAMEX/SANEX(Baron et al. 2001), and GANEX(Miguirditchian et al. 2007). None of these 
existing processes have been sufficiently developed for large scale deployment and they are potentially difficult to operate and control.(DOE 2010b) A better fundamental understanding of the chemistry of actinides and lanthanides in aqueous and organic solutions will greatly help in the development of a more efficient and cost effective process. Once developed, the process will need to be scaled-up and integrated with other processes in a flowsheet.

2. Management of process off-gasses to meet U.S. regulatory constraints. While every nation reprocessing fuel from power reactors maintains fission gas releases to a level that is safe for the environment and human health, the U.S. employs regulations based on the assumption that fuel from 1000 power reactors would be reprocessed.(Mcmahon et al. 2010) These regulations (40CFR190 and 10CFR20) mean that fission gas management is far more complicated in the U.S. than other countries. The isotopes ${ }^{85} \mathrm{Kr},{ }^{129} \mathrm{I},{ }^{3} \mathrm{H}$, and potentially ${ }^{14} \mathrm{C}$, need to be captured and immobilized. Several reviews of potential technologies for their removal have been documented.(Gombert et al. 2008; IAEA 1980a, b, 1987; Jubin et al. 2012) There remain several challenges. First is the exceedingly high decontamination efficiency required for iodine (plant wide DF of 380 to 8000 ) combined with the data that suggest that $>2 \%$ of the iodine remains in the aqueous stream leaving the dissolver and is emanated from virtually all vessel vent and process off-gas streams in small concentrations. Second is the capture of krypton which currently requires cryogenic separations from a gas stream devoid of any gasses except for nitrogen and noble gasses. Although this is a relatively proven technology, it is expensive and typically captures xenon which is non-radioactive and at much higher concentrations than krypton. Once krypton is captured, it isn't clear how to manage it. Regulatory requirements suggest it can be vented after the fuel that generated it has cooled for a total of 30 years. But, $\mathrm{Kr}$ decays to $\mathrm{Rb}$ which is a reactive liquid at storage temperatures.(Klett 1981) Tritium may be removed sufficiently from the fuel by a voloxidation process, but, that process is unproven and adds cost and risk to a reprocessing facility. If tritium remains in the fuel going to the dissolver, it will contaminate virtually every liquid stream within the reprocessing plant and thus could require the separation of tritium from a large volume of liquid process streams, or expensive disposal of those streams. Alternatively, it could result in the requirement to immobilize all process liquids, which would result in large volumes of waste. New methods are needed to capture and manage fission gasses for the success of a future U.S. reprocessing facility.

3. For many sustainable fuel cycles, MAs would be transmuted in targets or fuels. Fast-, thermal-, or epithermal-spectrum reactors can be used to transmute MAs. Fast-reactors in particular may be able to burn fuel in excess of $100 \mathrm{GWd} / \mathrm{t}$ which far exceeds the burnup of fuel in LWRs (typically $20-50 \mathrm{GWd} / \mathrm{t}$ ). Electrochemical processes have been successfully employed for fast reactor fuel reprocessing (for uranium recovery) in the U.S.(Li et al. 2005) However, these processes would likely not be scalable to process large amounts (thousands of tons per year) of light water reactor fuel. They better fit a dispersed reprocessing capability, co-located with several fast reactors, rather than a large-scale centralized reprocessing capability.

Electrochemical processes currently do not achieve high degrees of purity for the TRU elements, and require fast reactors to burn transmutation fuel from their products.

4. Waste forms and processes need to be developed as an integral part of separations technology development. As separations processes are developed, unique waste streams arise that must be managed in a safe, environmentally responsible and cost effective way. Although borosilicate glass is well demonstrated for the treatment of HLW streams,(Vienna 2010) it still remains a 
problematic process if not thoroughly developed and demonstrated for a unique waste stream as evidenced by the process difficulties experienced at the Rokkasho Reprocessing Plant (RRP). ${ }^{a}$ So as new reprocessing schemes are developed, specific waste forms and processes must be developed. Glass is also not an appropriate waste form for many of the steams resulting from potential separations technologies (e.g., undissolved solids and salts from electrochemical processing, gaseous fission product streams, and technetium). New waste forms must therefore be developed, tested, and demonstrated concurrently with the separations technology development. Additionally, the performance of any waste form is of paramount importance. Even with glass, there is significant uncertainty in performance due to a lack of understanding of the basic processes that control the release of radionuclides over millennia. This has resulted in an overly conservative glass release model for the Yucca Mountain performance assessment which would require unnecessarily expensive engineered barriers to overcome if applied to commercial reprocessing wastes. An international collaboration has begun and will not only help these scientific advances be realized more quickly, but an international consensus on corrosion rate will lessen the complications inherent in the qualification of waste forms and may reduce the conservatism in U.S. glass corrosion estimates.(Ryan et al. 2011a) Once the rate law has been developed and demonstrated on HLW glass, it will be applied to other waste forms requiring long service life such as the forms for I-129, Tc-99, and TRU.

These fundamental research gaps are shown schematically in the following figure.

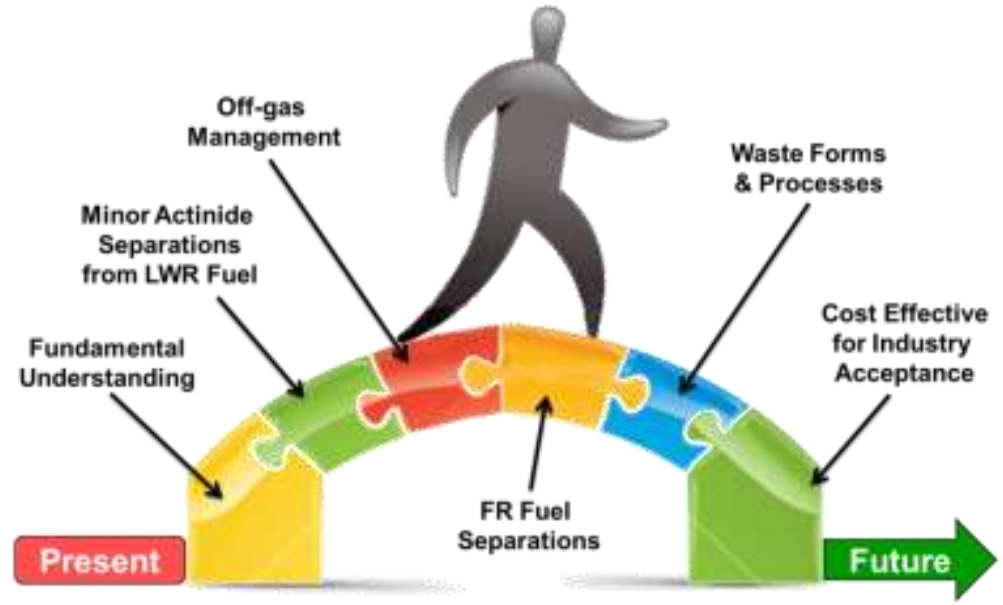

Research gaps for a full-recycle fuel cycle show schematically on the foundations of fundamental understanding and industrial acceptance

a JNFL presentation to PNNL and DOE-EM on March 3, 2010 titled "Glass Melter Operation in Active Test at Rokkasho Reprocessing Plant," followed by a series of internet news articles related to the RRP vitrification difficulties such as www.cnic.jp/english/newsletter/nit125/nit125articles/rokkasho.html. 


\subsection{Limited Recycle}

There are a broad range of limited recycle cases with a near continuum progression of treatments. These range from complete separations of actinides from UNF, to a limited number of passes through a reactor (as opposed to unlimited passes in the full recycle fuel cycle), to minimal treatment of UNF preparing it for reuse in a reactor (for example a heavy water reactor). Sevougian et al. performed an initial survey of fuel cycle options including limited recycle options.(Sevougian et al. 2011) ${ }^{\mathrm{b}}$ The processes involved may include simple removal of gaseous fission products and reformation of fuel pellets as typified by the 'DUPIC' process and extraction of uranium from the fission products using reactive gas processing. The technology development requirements for such a fuel cycle are as broad as the list of options themselves. The Campaign is performing limited proof-of-principle type studies on a number of promising limited recycle separations options to support the Fuel Cycle Options Screening effort.

Most limited recycle processes have two aspects in common: 1) off-gas treatment will be required to some extent and 2) radioactive wastes will be generated by the processing of UNF that will need disposal. The technology development requirements of these limited recycle concepts are being addressed in a general fashion as described in the full recycle section above.

\subsection{Open Cycle}

Open fuel cycle (once-through) requires separations and waste management research. To extend the sustainability of the open fuel cycle, sources of uranium previously considered too expensive and having too great of an environmental impact need to be considered. Two such sources are considered promising: 1) seawater contains over 10 billion MT of uranium (an effectively infinite supply), unfortunately it is distributed in small (3.2 ppb) concentrations, and 2) phosphate minerals such as monazite and other sources in the earth's crust contain over an estimated trillion MT of uranium, at concentrations ranging from 0.1 to $1000 \mathrm{ppm}$.

b Currently, a complete study and screening of fuel cycle options is underway. The results of this study will be incorporated into the program plan once available. 


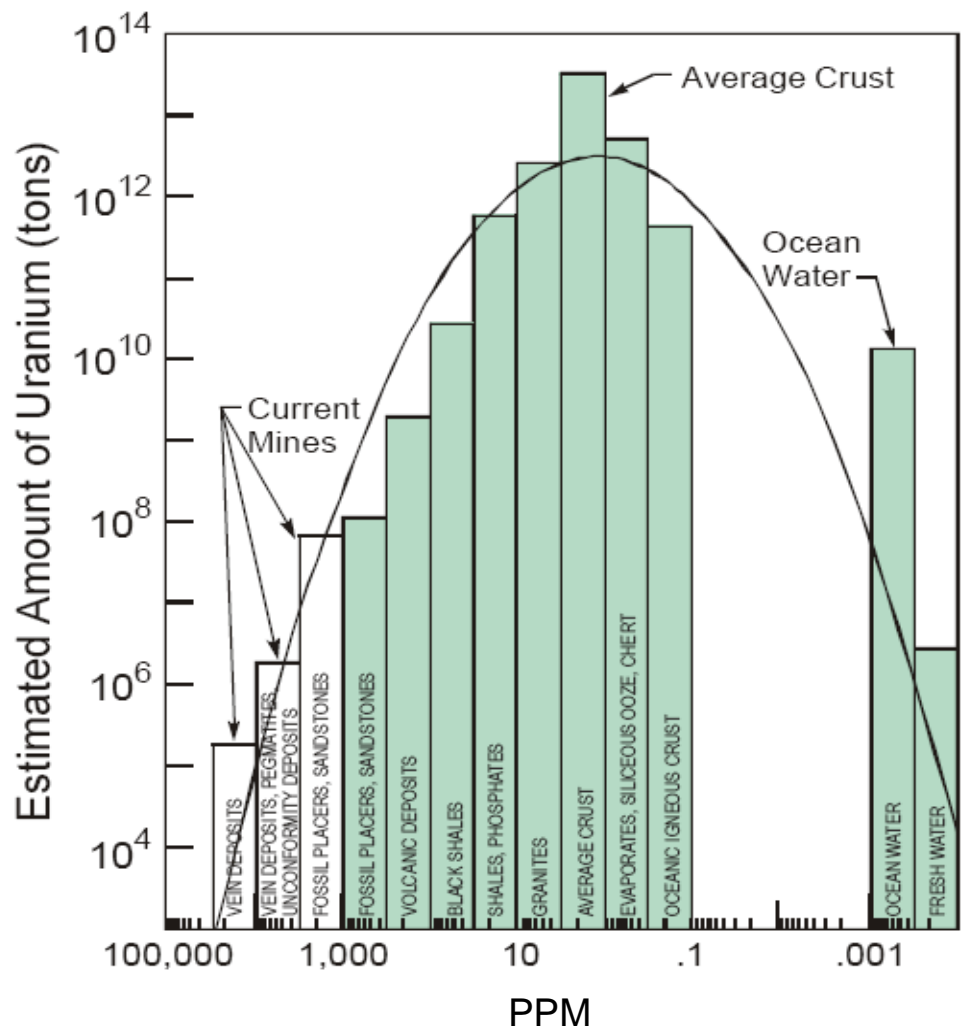

Uranium abundance as a function of concentration for various sources. ${ }^{c}$

The primary focus of fuels resource research conducted by the campaign is in the area of optimizing the cost of uranium extraction from seawater. To perform this, the fundamental binding chemistry of uranium must be understood. With that understanding, researchers hope to increase the capacity and selectivity of binding agents that can be employed as a part of a robust, passive seawater extraction system with minimal biofouling impacts. There is also the possibility of deploying a uranium getter material as part of existing actively circulated seawater systems such as desalinization or reactor cooling systems. However the availability of such a resource may prove to be insufficient. The research effort for extracting uranium from seawater began as a 3-year research effort in FY-11 with the goal of doubling the baseline sorption capacity previously established by Japanese researchers.(Tamada et al. 2006) Following the 3-year effort, an evaluation of the results along with an independent cost estimate will be performed to determine if additional research effort is warranted.

An additional area of open fuel cycle research is the potential to "condition" fuel to place it in a more stable form or matrix for long term storage. While this option directly supports the open cycle, it is also compatible with possible future processing options, including reprocessing. Possible options in this area could include removal of volatile fission gasses and repackaging the fuel into more durable containers that could be safely stored for up to a century or more.

\footnotetext{
${ }^{\mathrm{c}}$ http://www.americanenergyindependence.com/library/images/nuclear/Uranium01.htm
} 
A final area of potentially game changing technology development with respect to any fuel cycle is the development of methods to quickly and efficiently respond to unanticipated nuclear incidents (e.g., Fukushima Daiichi, Chernobyl, and Three Mile Island) or acts of terrorism (e.g., dirty bombs, reactor sabotage, etc.). Developing a set of solutions that would be made available to quickly respond to a nuclear incident may significantly reduce the impacts of such an incident on the environment and human health. Although no research has begun to address this potential area of technology development, it shows the potential for promise. Possible examples in this area would be materials to capture or separate volatile iodine from air, materials to remove cesium from liquid discharges, and technologies to quickly and economically immobilize contaminated liquid or solids (such as soils). 


\section{RESEARCH AND DEVELOPMENT APPROACH}

\subsection{Research Principles}

The SWF Campaign is focused on providing the science, research, development, enabling technologies, modeling and simulation, and systems engineering support to enable advanced fuel cycles to be evaluated and considered in the U.S. Three key principles guide the RD\&D within the campaign:

- Technological advancements must have a strong scientific basis.

- Technology development must consider not only testing and performance evaluation but also scale-up, operational requirements/constraints, materials accountancy, manufacturability, safety, cost, and licensing.

- The technologies must be amenable to cost-effective deployment by the nuclear industry.

The SWF Campaign will employ a dual path approach to developing technologies. This approach involves continuing to develop and demonstrate evolutionary technologies (such as aqueous separations, electrochemical separations, glass ceramic waste forms, etc.), while investigating new and transformational technologies (e.g., room temperature $\mathrm{Kr}$ separations, single step MA separations, etc.).

\subsection{Research Objectives}

The campaign is organized into major objectives which are described below along with the expected outcomes.

\begin{tabular}{|c|c|c|}
\hline Objective & Description & Targeted Outcomes \\
\hline $\begin{array}{l}\text { Fundamental } \\
\text { Science/Modeling and } \\
\text { Simulation }\end{array}$ & $\begin{array}{l}\text { Develop new tools and methods to } \\
\text { support a science-based approach to } \\
\text { development of separations processes } \\
\text { and waste forms. }\end{array}$ & $\begin{array}{l}\text { Create the scientific underpinnings, including } \\
\text { modeling methods, and integrate them into } \\
\text { the applied research and engineering } \\
\text { development activities. } \\
\text { Develop methods to perform separations and } \\
\text { waste management research more quickly and } \\
\text { less expensively. } \\
\text { Generate data to support engineering } \\
\text { development and modeling/simulation for } \\
\text { both separation processes and waste forms. }\end{array}$ \\
\hline $\begin{array}{l}\text { Sigma Team for Minor } \\
\text { Actinide Separations }\end{array}$ & $\begin{array}{l}\text { Formed in FY-2009 to provide the } \\
\text { scientific basis for more efficient } \\
\text { separation methods for americium and } \\
\text { other minor actinides to greatly improve } \\
\text { the overall benefit of fuel recycle. }\end{array}$ & $\begin{array}{l}\text { Develop and demonstrate cost effective } \\
\text { method(s) to separate minor actinides from } \\
\text { HLW raffinate stream to enable TRU recycle } \\
\text { from LWR fuels. }\end{array}$ \\
\hline Off-Gas Sigma Team & $\begin{array}{l}\text { Formed in FY-10 to integrate and } \\
\text { coordinate activities directed towards } \\
\text { the capture and immobilization of the } \\
\text { volatile and semi-volatile radionuclides } \\
\text { from fuel recycling. The radionuclides } \\
\text { of interest include I-129, C-14, Kr-85 } \\
\text { and H-3. }\end{array}$ & $\begin{array}{l}\text { Develop and demonstrate integrated off-gas } \\
\text { management processes for aqueous } \\
\text { separations of LWR fuel and electrochemical } \\
\text { separations of fast reactor fuels. } \\
\text { Develop waste forms for these difficult to } \\
\text { immobilize components. }\end{array}$ \\
\hline $\begin{array}{l}\text { Advanced Aqueous } \\
\text { Separations }\end{array}$ & $\begin{array}{l}\text { Improve advanced aqueous separations } \\
\text { technologies by focusing step-change } \\
\text { improvements in process monitoring } \\
\text { and control, transformational sampling } \\
\text { methods, measuring solvent degradation } \\
\text { in realistic process conditions, advanced } \\
\text { methods of TRU product conversion, } \\
\text { etc. }\end{array}$ & $\begin{array}{l}\text { Demonstrate the proof-of-principle at } \\
\text { appropriate scale of advanced aqueous } \\
\text { separations processes and analytical } \\
\text { techniques. Improvements applicable to } \\
\text { generic aqueous separation processes are } \\
\text { currently under development, but will be } \\
\text { applied to reference technologies from the } \\
\text { minor actinide sigma team. }\end{array}$ \\
\hline
\end{tabular}




\begin{tabular}{|c|c|c|}
\hline Objective & Description & Targeted Outcomes \\
\hline Advanced Waste Forms & $\begin{array}{l}\text { Develop next generation waste forms } \\
\text { and waste management concepts with } \\
\text { significantly higher performance. In } \\
\text { this sense, performance means cost, } \\
\text { volume, and stability over sufficient } \\
\text { time scales. }\end{array}$ & $\begin{array}{l}\text { Demonstrate the application of waste forms } \\
\text { for problematic waste streams with order of } \\
\text { magnitude or higher performance } \\
\text { improvement. }\end{array}$ \\
\hline $\begin{array}{l}\text { Waste Form } \\
\text { Performance over } \\
\text { Geologic Timescales }\end{array}$ & $\begin{array}{l}\text { Understand the corrosion behavior of } \\
\text { waste forms to predict the retention of } \\
\text { radioelements during long-term disposal } \\
\text { in a geologic repository. }\end{array}$ & $\begin{array}{l}\text { Establish an international consensus glass } \\
\text { corrosion rate law through scientific } \\
\text { understanding of the glass corrosion } \\
\text { mechanism over long time periods. } \\
\text { Provide performance data for the design of } \\
\text { geologic repositories in a variety of geologic } \\
\text { environments. } \\
\text { Expand the process to include other key waste } \\
\text { forms such as those for immobilization of I- } \\
129, \text { Tc- } 99 \text {, and TRU. }\end{array}$ \\
\hline $\begin{array}{l}\text { Electrochemical } \\
\text { Separation }\end{array}$ & $\begin{array}{l}\text { Conduct the research and create the } \\
\text { technologies necessary to enable TRU } \\
\text { separation from fast reactor fuel. }\end{array}$ & $\begin{array}{l}\text { Demonstrate an integrated, cost effective } \\
\text { method for electrochemical separations of } \\
\text { metallic fast reactor fuel and improved } \\
\text { process control and inventory analyses. }\end{array}$ \\
\hline $\begin{array}{l}\text { Transformational } \\
\text { Separations Approaches }\end{array}$ & $\begin{array}{l}\text { Investigate transformational } \\
\text { technologies that are much less mature } \\
\text { but could be a "game changer" for } \\
\text { recycling. }\end{array}$ & $\begin{array}{l}\text { Perform proof-of-principle studies on } \\
\text { potential high performance separation } \\
\text { approaches. } \\
\text { Supply data on advanced separations } \\
\text { approaches for the evaluation and screening } \\
\text { of different fuel cycle options. }\end{array}$ \\
\hline Fuel Resources & $\begin{array}{l}\text { Develop high performance extractant } \\
\text { systems for uranium extraction from } \\
\text { seawater. }\end{array}$ & $\begin{array}{l}\text { Demonstrate an extractant material with twice } \\
\text { the capacity for uranium and sufficient } \\
\text { selectivity and stability to be used in seawater } \\
\text { extraction. }\end{array}$ \\
\hline
\end{tabular}

\subsection{Prioritization and Expert Review}

The nine objectives described above respond to the programmatic guidance described in Section 1 and are directly focused on filling the high priority technological gaps described in Section 2 for the fast reactor, limited recycle, and open fuel cycle options. There will always be a need to prioritize the research performed within and between these objectives. Between objectives, priorities are determined largely by the need to maintain an effort in each of the objectives and support the high priority research for each of the fuel cycle options. Beyond this obvious desire for balance in the program, particular emphasis is given to technologies required to enable the most effective fuel cycle option(s) as the highest priority. Second priority is given to the development and demonstration of technologies with significantly higher performance than existing technologies (for example, substantial improvements in nuclear material accountancy, order of magnitude improvement in waste form durability, processes resulting in reduced construction/operating costs or major improvements in safety and licenseability). The third priority goes to the development and demonstration of backup technologies for high risk or high cost operations. The final priority is assigned to the development of methods and capabilities to develop new and improved separations and waste forms of the future. These basic tenets of prioritization are also applicable within objectives. A number of multi-variant optimization schemes to evaluate these priorities were attempted to prioritize work scope. However it was found that expert judgment applied through the priority descriptions yielded the most meaningful results. 
To this end a number of peer review panels have been convened to evaluate the conduct of research and help prioritize research within the SWF Campaign. These reviews panels were comprised of world renowned experts in the area of research to evaluate the methods, prioritization of efforts, and reliability of the results from separate focused efforts within the campaign. Technical peer review efforts generated a summary document that describes the panel, their charter, the review method, and findings/recommendations. Other expert panels were used to review white paper proposals for transformational research or new research capabilities.

- Transformational Separations Approaches and Capability Development reviewed June 2009.(Todd 2009)

- Electrochemical Separations Research and Development reviewed March 2009.(Garcia et al. 2009)

- Advanced Waste Management Approaches reviewed July 2010.(Vienna 2011)

- Limited Recycle Separations Approaches reviewed January 2011. (Todd 2011)

- Minor Actinide Sigma Team technical peer review May 2011.(Nitsche et al. 2011)

- Off-gas Sigma Team technical peer review June 2011.(Jubin 2011)

- Glass Corrosion Research technical peer review July 2011.(Ryan et al. 2011b)

In addition to external peer reviews, the SWF National Technical Director (NTD) and his deputy work closely with the Federal Campaign Managers, the Technical Integration Office, and National Technical Director's from other campaigns to develop an appropriately focused campaign. As will be described in the following subsection, Campaign research is performed in the context of interactive groups that help to ensure focus on the appropriate technical gaps.

A Campaign relevancy review was performed in June 2012.(Harmon 2012) The review was performed by independent experts in the area of separations and waste forms which evaluated several aspects of the campaign as they respond to overall DOE guidance. The results of this review are generally summarized below:(Harmon 2012)

- $\quad S \& W F$ has an excellent program in place and high quality results are being achieved. Numerous publications (400-500) and accomplishments show excellent productivity and results-oriented work.

- We are impressed by the caliber and breadth of technical managers and researchers that are involved. You have engaged the top people in the country in all areas of work. We know them and respect them.

- We recognize the difficulty in managing this program in the rapidly changing environment and continued uncertainties ahead - for both DOE-NE and contractors. The management team has learned to cope with change, while still maintaining commitment and enthusiasm among the program participants. In short, the program is in good hands.

- You have made excellent use of industry, national labs, and universities. Your program has been proactive in engaging the universities via the Nuclear Energy University Program (NEUP) and through direct contracts from $S \& W F$ Campaign.

In addition, the relevancy of different aspects of the program were judged:

\section{R\&D Activity}

Relevancy Assessment

\begin{tabular}{l|l} 
Chairman & Panel Member
\end{tabular}




\begin{tabular}{|l|c|c|}
\hline $\begin{array}{l}\text { Fundamental Science and Methods Development / } \\
\text { Modeling \& Simulation }\end{array}$ & Moderate to High & Moderate to High \\
\hline Sigma Team for Minor Actinide Separations & Moderate to High & Moderate to High \\
\hline Sigma Team for Off-gas Capture and Immobilization & High & Moderate \\
\hline Advanced Aqueous Separations & Moderate to High & Moderate to High \\
\hline Advanced Waste Forms / Waste Form Processing & High & High \\
\hline Waste Form Performance Over Geologic Timescale & High & High \\
\hline Domestic Electrochemical Processing & Moderate & Moderate \\
\hline Transformational Separation Approaches & Moderate & Moderate \\
\hline Fuel Resources (U Extraction from Seawater) & Moderate & Moderate to High \\
\hline
\end{tabular}

\subsection{Working Teams}

The SWF Campaign research is broad in scope spanning across nine different objectives and three different fuel cycle options and involving numerous fuel types. The outcomes of this research are typically the demonstration of a scientifically based solution at engineering scale. This breadth of research cannot be effectively performed by any single researcher as no one is simultaneously an expert in fundamental science and industrial application of technologies. It is often the case that no single organization can perform the range of research required as effectively as a multi-institutional team. Scientific and engineering research is most often performed simultaneously by multi-institutional, multidisciplinary teams within the SWF Campaign. These teams are typified by the Sigma teams, but the general concept is applied to all of the research objectives to some extent.

Each Sigma team is led by a highly experienced practitioner in the research area of focus for that team and includes participants from multiple organizations with multiple research experiences, who form the "core-team. Each "core-team" includes scientists versed in each primary area of research and engineers versed in the design and operation of nuclear processes. The teams meet regularly to discuss the latest results and adjust research focus as needed. The teams also call upon others from their colleagues in laboratories and universities to perform research tasks and evaluate data. Currently two Sigma Teams are employed by the Campaign: the Off-gas Management Team and the Minor Actinide Separations Team.

Several other objectives utilize teams of one sort or another. For example, the Waste Form Performance over Geologic Timescales objective is organized around a multi-national team with the aims of developing sufficient scientific understanding of the processes responsible for the long-term rate of radionuclide release that a consensus rate law will result. This team approach to research will continue, expanding as appropriate, to meet the needs of the Campaign.

Two fundamental tenets of the SWF Campaign are the scientific understanding of the processes being developed and the drive toward practical industrial application of the technologies. To be successful, research teams require participation of university and industry representatives. This is accomplished through several mechanisms. First, university professors are involved through direct campaign funding of their research efforts in a number of areas. University professors are also involved through the indirect funding mechanism of Nuclear Energy University Programs (NEUP) where the project selection criteria are based, in part, according to applicability to current Campaign objectives. Industrial participation has primarily been facilitated by the Indefinite Duration Indefinite Quantity (IDIQ) contracts put in place by DOE-NE. Several IDIQ tasks support the campaign, chief among them, relative to the SWF Campaign are: Task-1 "Participate in Campaign Meetings", Task-8 "Zirconium Recovery", and Task-9 "Waste Quantities." 


\subsection{A Note on Facilities}

Nuclear separation and waste form research and demonstration require highly specialized facilities because of the radioactivity and safeguards and security requirements. The need for preserving or developing specialized facilities for this purpose, and maintaining technical expertise cannot be overstated. There are facility and infrastructure challenges throughout the DOE complex. Specifically, the number of nuclear facilities is shrinking and their conditions are deteriorating at a pace greater than new or refurbished facilities are being brought on line.(DOE 2011a) As the implementation of the SWF Campaign objectives moves forward, these facilities become critical for the technology and integrated system demonstrations. Pilot-scale demonstration of one or more fuel recycle options is needed to deploy those options commercially. Ultimately, lead test assemblies (LTA) will be fabricated, irradiated and examined to support the licensing of a new fuel, and thereby fuel cycle. According to the current program schedule, LTAs will be needed in roughly 20-25 years; however, it will take much of that time to bring such a facility on-line and prepare the feed materials needed for the LTAs.

The need to maintain and improve research capabilities and facilities is critical to the long-term success of nuclear energy in the U.S. as recommended by the BRC. 


\section{PROGRAM SCHEDULE}

With the very long time required to implement a fuel cycle component, not to mention transition to a new cycle, intermediate schedule objectives are critical. The schedule described below is based, in part, by the Implementation Plan for Developing Sustainable Fuel Cycle Options.(DOE 2010b) This plan calls for the availability of the first LTA for fast reactor fuel cycles and/or limited recycle options by 2037. The schedule for open fuel cycle accomplishments are somewhat subjective, however programmatic guidance was delivered for these too. Based on these schedule guidance, the following schedule is based on five and ten year increments.

The upper level schedule is shown below. In addition to the current activities, new and innovative separations technologies will be periodically evaluated and incorporated into the program as appropriate. 


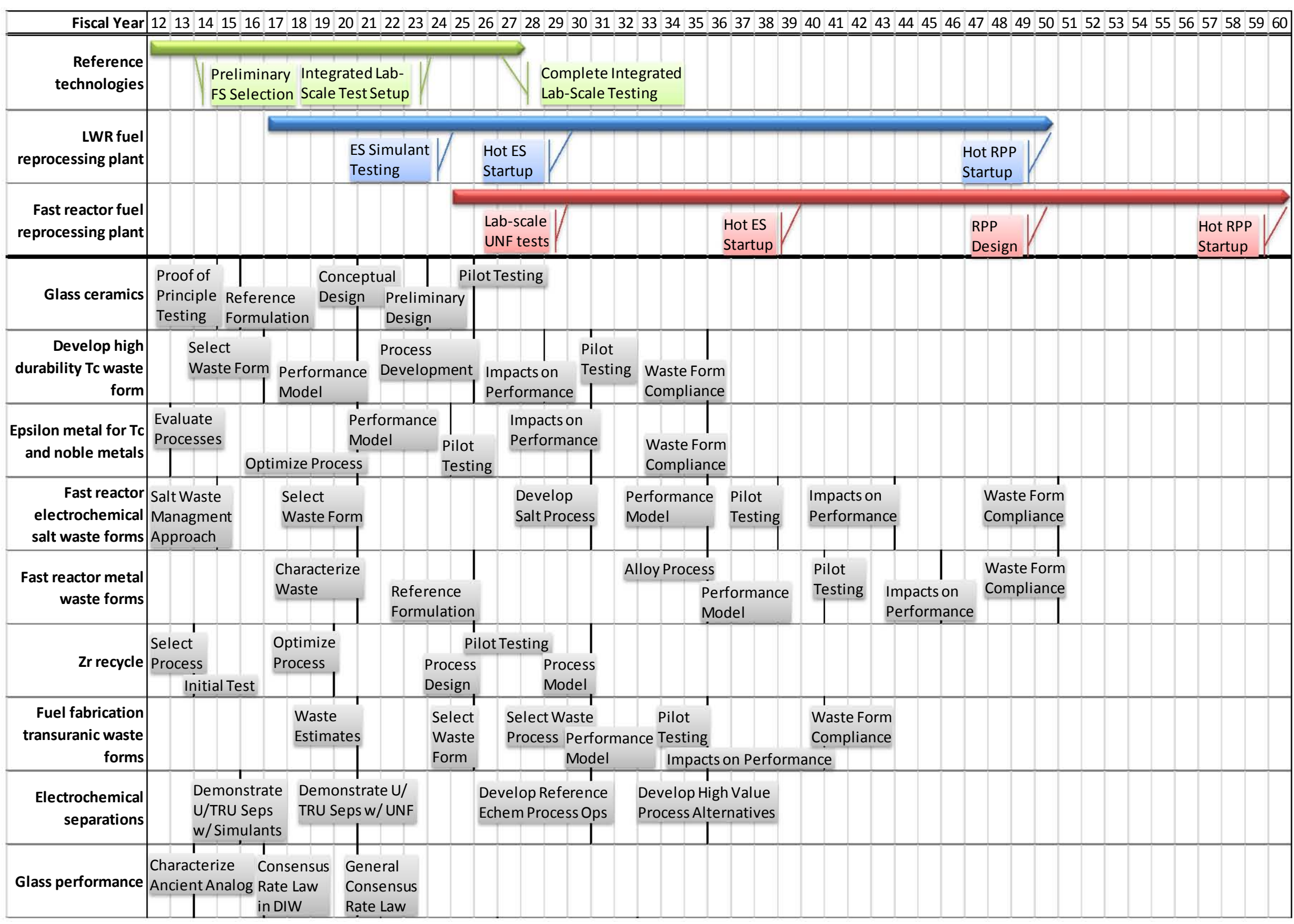




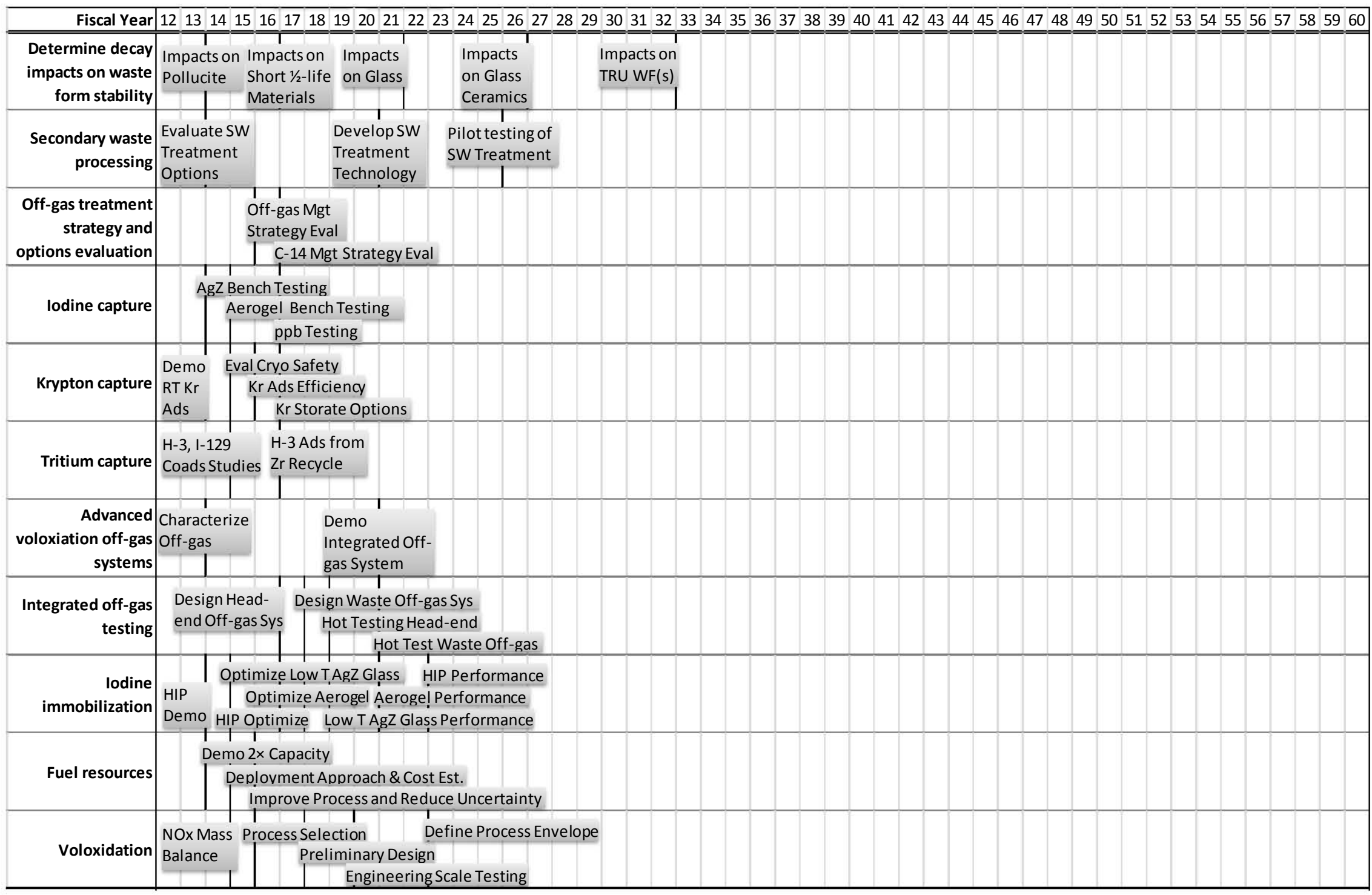


Separations and Waste Forms Campaign Implementation Plan

November 26, 2012

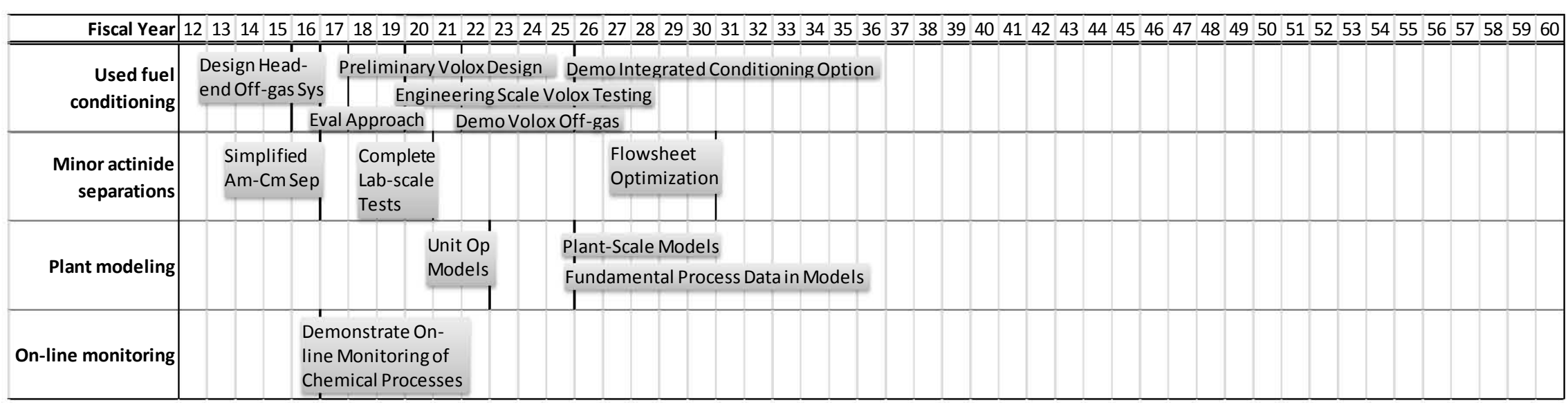




\section{CAMPAIGN INTERFACES}

Separations process flowsheets are substantially influenced by specifications of the desired fuel for the recycling reactor and desired waste forms for the repository. Waste processes and waste forms are substantially influenced by the separations and fuels fabrication flowsheets, which identify the primary waste sources. The SWF Campaigns has critical linkages to the Advanced Reactor Program, Advanced Fuels Campaign, Fuel Cycle Options, and Used Fuel Disposition Campaigns. All separation processes must be safeguarded to ensure no fissile material is diverted and therefore another key interface is the MPACT Campaign. The interfaces are maintained through joint campaign management, by joint working group meetings, and by coordinated research activities. Campaign activities are also closely coordinated with DOE-NE International Nuclear Cooperation office, DOE's Office of Environmental Management and the Office of Science and the National Nuclear Security Administration.

The Separations and Waste Form Campaign also participates extensively with international working groups. The prime international collaborations are with France, Japan, Russia, China, Republic of Korea, and the Czech Republic through bilateral agreements and a trilateral agreement. Less-formal collaborations are ongoing with the United Kingdom, Belgium, and other nations. Specific activities are described in the Separations and Waste Form FY 2011 Accomplishments Report. 


\section{REFERENCES}

Baron, P., X. Heres, M. Lecomte, and M. Masson. 2001. "Separation of the Minor Actinides: The Diamex-Sanex Concept," Global 2001, American Nuclear Society, Paris, France.

DOE. 1997. Linking Legacies: Connecting the Cold War Nuclear Weapons Production Processes to Their Environmental Consequences, DOE/EM-0319, U.S. Department of Energy, Office of Environmental Management, Washington, D.C.

DOE. 2010a. Nuclear Energy Research and Development Roadmap, U.S. Department of Energy, Office of Nuclear Energy, Washington, D.C.

DOE. 2011a. Nuclear Separations Technologies Workshop Report: Getting from Where We Are to Where We Want to Be in Nuclear Separations Technologies, U.S. Department of Energy, Washington, D.C.

DOE. 2010b. Research Objective 3 Implementation Plan: Developing Sustainable Fuel Cycle Options, FCRD-TIO-2011-000025, U.S. Department of Energy, Office of Nuclear Energy, Washington, D.C. DOE. 2011b. U.S. Department of Energy Strategic Plan, DOE/CF-0067, U.S. Department of Energy, Washington, D.C.

Garcia, E., B. Mishra, T.A. Todd, and J. Withers. 2009. Electrochemical Separations Research \& Development Program Assessment, U.S. Department of Energy, Office of Nuclear Energy, Idaho Falls, ID.

Gombert, D., W.L. Ebert, J.C. Marra, R.T. Jubin, and J.D. Vienna. 2008. "Global Nuclear Energy Partnership Waste Treatment Baseline," Atalante 2008.

Hamilton, L.H., B. Scowcroft, M.H. Ayers, V.A. Bailey, A. Carnesale, P.V. Domenici, S. Eisenhower, C. Hagel, J. Lash, A.M. Macfarlane, R.A. Meserve, E.J. Moniz, P.F. Peterson, J.W. Rowe, and P. Sharp. 2012. Blue Ribbon Commission on America's Nuclear Future: Report to the Secretary of Energy, Blue Ribbion Commission on America's Nuclear Future (BRC), Washington, D.C.

Harmon, H.D. 2012. Relevancy Review of Separations and Waste Forms Campaign, Aiken, SC.

IAEA. 1980a. Radioiodine Removal in Nuclear Facilities: Methods and Techniques for Normal and Emergency Situations, TRS-201, International Atomic Energy Agency, Vienna, Austria.

IAEA. 1980b. Separation, Storage, and Disposal of Krypton-85, TRS-199, International Atomic Energy Agency, Vienna, Austria.

IAEA. 1987. Treatment, Conditioning and Disposal of Iodine-129, TRS-276, International Atomic Energy Agency, Vienna, Austria.

Jubin, R.T. 2011. Report of External Review for Off-Gas Sigma Team Activities, Oak Ridge National Laboratory, Oak Ridge, TN.

Jubin, R.T., N.R. Soelberg, D.M. Strachan, and G. Ilas. 2012. Position Paper on Practicable Performance Criteria for the Removal Efficiency of Volatile Radionuclides, FCRD-SWF-2012-000091, Oak Ridge National Laboratory, Oak Ridge, TN.

Klett, R.D. 1981. Krypton-85 Disposal Program Conceptual Design Phase: Final Report, SAND811957, Sandia National Laboratories, Albuquerque, NM.

Li, S.X., T.A. Johnson, B.R. Westphal, K.M. Goff, and R.W. Benedict. 2005. "Experience for Pyrochemical Processing of Spent EBR-II Driver Fuel," Global 2005, American Nuclear Society. Lumetta, G.J., J.C. Carter, A.V. Gelis, and G.F. Vandegrift. 2010. "Combining Octyl(Phenyl)-N,NDiisobutyl-Carbamoylmethylphosphine Oxide and Bis-(2-Ethylhexyl)Phosphoric Acid Extractants for Recovering Transuranic Elements from Irradiated Nuclear Fuel," Nuclear Energy and the Environment Symposium, Vol. 1046, 107-118 pp. American Chemical Society.

Mcmahon, K.A., N.E. Bixler, J.E. Kelly, M.D. Siegel, R.F. Weiner, and K.A. Klein. 2010. Review of the Technical Bases of 40 CFR Part 190, SAND2010-3757, Sandia National Laboratories, Albuquerque, NM. 
Miguirditchian, M., L. Chareyre, X. Hérès, C. Hill, P. Baron, and M. Masson. 2007. "Ganex: Adaptation of the Diamex-Sanex Process for the Group Actinide Separation," Global 2007, American Nuclear Society.

Nitsche, H., L. Tavlarides, and C. Ekberg. 2011. Summary Report of the Peer Review of the Sigma Team for Minor Actinide Separations.

Ryan, J.V., W.L. Ebert, J.P. Icenhower, D.M. Strachan, C.I. Steefel, L.J. Criscenti, I.C. Bourg, R.E. Williford, K.A. Murphy, C.G. Pantano, E.M. Pierce, D.K. Shuh, G.A. Waychunas, J.C. Marra, J.D. Vienna, P. Zapol, and C.M. Jantzen. 2011a. Technical Program Plan for the International Technical Evaluation of Alteration Mechanisms (I-Team), PNNL-21031, Pacific Northwest National Laboratory, Richland, WA.

Ryan, J.V., J.D. Vienna, W.L. Ebert, J.P. Icenhower, D.M. Strachan, C.I. Steefel, P. Zapol, L.J. Criscenti, I.C. Bourg, and E.M. Pierce. 2011b. Peer Review and Response for the International Technical Evaluation of Alteration Mechanisms (I-Team), FCRD-SWF-2011-000342, Pacific Northwest National Laboratory, Richland, WA.

Sevougian, S.D., M. Gross, E. Hardin, E. Hoffman, R. Mackinnon, L. Price, W. Halsey, J.L. Buelt, J. Gehin, M. Mullen, T.A. Taiwo, M. Todosow, and R.A. Wigland. 2011. Initial Screening of Fuel Cycle Options, FCRD-SYSE-2011-000040, Rev. 0, Sandia National Laboratories, Albuquerque, NM.

Tamada, M., N. Seko, N. Kasai, and T. Shimizu. 2006. "Cost Estimation of Uranium Recovery from Seawater with System of Braid Type Adsorbent," Transactions of the Atomic Energy Society of Japan, 5:358-363.

Todd, T.A. 2009. email, "2 Page White Papers Needed," to Distribution, June 30, 2009, Idaho Falls, ID. Todd, T.A. 2011. email, "Moc Peer Review Agenda and Instructions," to Distribution, January 14, 2011, Idaho Falls, ID.

Vienna, J.D. 2010. "Nuclear Waste Vitrification in the United States: Recent Developments and Future Options," International Journal of Applied Glass Science 1(3):309-321.

Vienna, J.D. 2011. "Selection of Innovative Waste Form Concepts for Study in the Separations and Waste Forms Campaign in Fiscal Year 2012," to T.A. Todd, September 16, 2011, Pacific Northwest National Laboratory, Richland, WA.

Weaver, B. and F.A. Kappelmann. 1968. "Preferential Extraction of Lanthanides over Trivalent Actinides by Monoacidic Organophosphates from Carboxylic Acids and from Mixtures of Carboxylic and Aminopolyacetic Acids," Journal of Inorganic Nuclear Chemistry, 30:263-272. 